\title{
Synthetic Seleno-Glutaredoxin 3 Analogs are Highly Reducing Oxidoreductases with Enhanced Catalytic Efficiency
}

\author{
Norman Metanis ${ }^{a, b, d}$, Ehud Keinana,b,d, ${ }^{*}$, and Philip E. Davison ${ }^{b, c, d,{ }^{*}}$ \\ a Department of Chemistry and Institute of Catalysis Science and Technology, Technion-Israel Institute of \\ Technology, Technion City, Haifa 32000, Israel \\ b The Scripps Research Institute, Departments of Molecular Biology, 10550 North Torrey Pines Road, La \\ Jolla, California 92037, USA \\ c Departments of Cell Biology and Chemistry, 10550 North Torrey Pines Road, La Jolla, California 92037, \\ USA \\ d Skaggs Institute for Chemical Biology, 10550 North Torrey Pines Road, La Jolla, California 92037, USA
}

\section{Abstract}

Selenoenzymes have a central role in maintaining cellular redox potential. These enzymes have selenenylsulfide bonds in their active sites that catalyze the reduction of peroxides, sulfoxides and disulfides. The selenol/disufide exchange reaction is common to all of these enzymes and the active site redox potential reflects the ratio between the forward and reverse rates of this reaction. The preparation of enzymes containing selenocysteine (Sec) is experimentally challenging. As a result, little is known about the kinetic role of selenols in enzyme active sites, and the redox potential of a selenenylsulfide or diselenide bond in a protein has not been experimentally determined. In order to fully evaluate the effects of Sec on oxidoreductase redox potential and kinetics, glutaredoxin 3 (Grx3) and all three Sec variants of its conserved ${ }^{11} \mathrm{CXX}^{14} \mathrm{C}$ active site were chemically synthesized. Grx3, Grx3(C11U) and Grx3(C14U) exhibited redox potentials of $-194,-260$ and $-275 \mathrm{mV}$, respectively. The position of redox equilibrium between Grx3(C11U-C14U) $(-309 \mathrm{mV})$ and thioredoxin (Trx) $(-270 \mathrm{mV})$ suggests a possible role for diselenide bonds in biological systems. Kinetic analysis is consistent with the hypothesis that the lower redox potentials of the Sec variants result primarily from the greater nucleophilicity of the active site selenium rather than its role as either a leaving group or a 'central atom' in the exchange reaction. The $10^{2}$ to $10^{4}$-fold increase in the rate of Trx reduction by the seleno-Grx3 analogs demonstrates that Oxidoreductases containing either selenenylsulfide or diselenide bonds can have physiologically compatible redox potentials and enhanced reduction kinetics in comparison with their sulfide counterparts.

\section{Introduction}

The unique role of selenium in biochemical systems was demonstrated by the discovery that selenocysteine ( $\mathrm{Sec}, \mathrm{U}$ ) is an essential part of the active site of the antioxidation enzyme glutathione peroxidase (GPx). ${ }^{1,2}$ The number of newly discovered selenoproteins grows steadily, triggering increased research interest in the biological functions of these enzymes. ${ }^{3}$, ${ }^{4} \mathrm{Sec}$ is viewed as the $21 \mathrm{st}$ amino acid in the natural repertoire, 3,4 and has been found in various prokaryotic and eukaryotic proteins. The $\mathrm{p} K_{\mathrm{a}}$ of the selenol group (5.7 in free Sec) is 3 units lower than that of the thiol group ( 8.5 in free Cys) and both are expected to be $\sim 1 \mathrm{p} K_{\mathrm{a}}$, unit

keinan@tx.technion.ac.il, dawson@scripps.edu.

Theresa Tiefenbrunn for discussions, and Dr. Jörg Zimmermann for data fitting. 
higher within a polypeptide chain. ${ }^{5}$ In addition, the selenolate anion is a stronger nucleophile than the analogous thiolate, and has been suggested to be a better leaving group. ${ }^{6}$ Many Sec residues in enzymes form transient selenenylsulfide bonds with proximal cysteine residues as part of their catalytic mechanisms. Although the redox potential of a selenenylsulfide bond in proteins has not been experimentally determined, its value was predicted to be within the range between the redox potentials of the disulfide and diselenide bonds. ${ }^{3}$ Additionally, diselenide bonds have not been rigorously characterized in proteins, and it has been suggested that thioredoxin, the most reducing oxidoreductase in $E$. coli ${ }^{7}$ would be unable to reduce the diselenide bond, leading to the assumption that diselenide bonds are nonexistent in natural proteins. ${ }^{8,9}$ However, the Sec-rich protein from zebrafish, zSe1Pa, was found to contain 17 Sec residues, ${ }^{10}$ suggesting that $z$ Se1Pa may contain a number of diselenide bonds. Sec residues, are often found in the active site of selenoenzymes, and have been found to be essential for their activity. Mutating the Sec residue to Cys in selenoenzymes usually results in decreased catalytic activity of up to 1000 -fold. $6,11,12$ Similarly, a Cys to Sec mutation in methionine$R$-sulfoxide reductase (MsrB2 and MsrB3) resulted in 100-fold increase in the catalytic activity of the enzyme, ${ }^{8}$ demonstrating the advantages of Sec in enzyme engineering.

The selenoproteins Sep15 and Se1M have homology to thioredoxin, defining a new class of selenoenzymes. ${ }^{13,14}$ The thiol/disulfide oxidoreductases of the thioredoxin superfamily, include the thioredoxins (Trx), glutaredoxins (Grx), protein disulfide isomerase (PDI), and bacterial protein-folding factor (DsbA), ${ }^{15}$ all sharing a similar molecular architecture, known as the Trx fold $\left(\alpha / \beta\right.$ fold). ${ }^{16,17}$ They also share the same active site motif -Cys-Xaa-Xaa-Cys(CXXC), with the $K_{\mathrm{a}}$, of the $\mathrm{N}$-terminal Cys thiol being lower than that of free Cys, ${ }^{18}$ ranging from 3.4 in DsbA ${ }^{19,20}$ to 6.3 in Trx. ${ }^{21,22}$ The selenoproteins Sep15 and Se1M have CXU and CXXU sequences in their active site. ${ }^{13,14,23}$ Although replacement of selenium by sulfur in the active site is expected to substantially modify the redox potential, no accurate potentials of these proteins have been determined. Furthermore, the effect of such replacement on the catalytic activity of oxidoreductases has not been studied.

The broad range of redox potentials, from $-125 \mathrm{mV}$ in DsbA to $-270 \mathrm{mV}$ in Trx, ${ }^{7}$ reflects the variability of the protein environment around the conserved active site motif, CXXC, and its geometry. Indeed, site-directed mutagenesis experiments have shown that changing the two $\mathrm{X}$ amino acids between the two Cys residues in this motif can significantly alter the redox potential. ${ }^{24,25,26,27,28}$ The observed redox potential of proteins in the Trx superfamily reflects the relative stability of the oxidized (disulfide) and reduced (dithiol) forms of the protein. On the basis of the protein sequence, it is difficult to predict the relative stability of these two forms. ${ }^{29}$ For example, both $\mathrm{Grx} 1{ }^{30}$ and Grx $3,{ }^{31}$ which act as hydrogen donors to ribonucleotide reductase (RR), share the same active site sequence (CPYC) and have 33\% sequence identity. ${ }^{32,33}$ Yet, their redox potentials vary by $35 \mathrm{mV} .^{7}$

The incorporation of Sec into proteins represents a non-trivial challenge. In Nature, this process is highly regulated, with the UGA termination codon being used to specify the insertion of Sec. 34,35 However, it is difficult to prepare selenoproteins using this approach with the traditional recombinant expression systems. ${ }^{36}$ An alternative strategy employs Sec instead of Cys in the growth medium of a cysteine-auxotrophic environment. ${ }^{37}$ This technique was used to prepare a Trx (Cys32Sec-Cys35Sec) mutant with only partial replacement (80\%) of all Cys residues in the protein by Sec. ${ }^{37}$ An alternative approach involves the chemical modification of wild-type proteins, as was achieved, by Hilvert et al in the preparation of selenosubtilisin. 38

Unfortunately, the chemical modification approach is limited to very few cases where a specific active-site residue is sufficiently prone to selective chemical modifications.

Chemical synthesis is an attractive strategy for incorporating Sec into polypeptides, as demonstrated by the solid-phase peptide synthesis (SPPS) of Sec variants of IL-8 by Clark- 
Lewis and coworkers. ${ }^{39}$ This approach was also used to study Sec fragments of Grx1(10-17) and analogs of $\alpha$-conotoxin ImI. $40,41,42$ The SPPS approach is significantly enhanced by the native chemical ligation (NCL) strategy, which allows the assembly of unprotected peptides to produce large proteins. ${ }^{43,44}$ The NCL methodology has proven useful in the efficient preparation of many proteins, 44,45 and was recently applied to the semisynthesis of selenoproteins using Sec instead of Cys at the ligation site. ${ }^{46,47,48,49,50}$ However, incorporation of Sec at positions other than the ligation site has not been demonstrated.

Here we report on the first synthesis and characterization of Sec substitutions into an oxidoreductase, yielding enzymes that contain selenenylsulfide and diselenide bonds. We have chosen Grx3 as a model oxidoreductase due to its intermediate redox potential within the Trx superfamily. ${ }^{7}$ An efficient chemical synthesis of Grx 3 was developed using conformationally assisted native chemical ligation ${ }^{51}$ followed by selective oxidation of the active site residues and alkylation of the cysteine at the ligation site. The native Grx3 and three active site Sec analogs were then synthesized to determine the effects of selenenylsulfide and diselenide bonds on the redox potential and equilibration kinetics of oxidoreductase enzymes.

\section{Results}

\section{Synthesis of Grx3 analogs}

To probe the role of Sec in oxidoreductase enzymes, we chemically synthesized four proteins: "wild-type" Grx3 (sGrx3), Grx3(C11U), Grx3(C14U), and Grx3(C11U-C14U). The Grx3 analogs were assembled from two synthetic peptide fragments by native chemical ligation (NCL, Figure 1). ${ }^{43}$ To facilitate ligation, Ala38, a solvent exposed residue in the middle of the sequence, was substituted with Cys. Machine-assisted Boc-SPPS was used to assemble the Sec containing thioester peptides, since it has been shown that incorporation of Boc-Sec(4$\mathrm{MeBzl})-\mathrm{OH}$ has low levels of epimerization and the 4-MeBzl side chain protecting group can be removed cleanly by HF. ${ }^{42}$ Thus, an efficient procedure for the synthesis of Boc-Sec(4$\mathrm{MeBzl})-\mathrm{OH}$ was developed, analogous to that reported by van der Donk for Fmoc-Sec(4MeOBzl)-OH (Scheme 1). ${ }^{48}$ Notable changes to the method include the synthesis of the (4MeBzl)-diselenide, using elemental selenium under bubbling $\mathrm{CO}_{(\mathrm{g})}, 52$ and the mild deprotection of the methyl ester using $\mathrm{Me}_{3} \mathrm{SnOH}_{.}{ }^{53}$ This strategy furnished $10 \mathrm{~g}$ of the desired product in 45\% overall yield. Four thioester (-COSR) peptides: Grx3(1-37)-COSR, Grx3(1-37) (C11U)-COSR, Grx3(1-37)(C14U)-COSR, Grx3(1-37)(C11U-C14U)-COSR, and a single Nterminal Cys peptide, Grx3(38-82)(A38C)-OH were synthesized and purified to yield 50-100 $\mathrm{mg}$ of each peptide.

\section{Conformationally assisted ligation of Grx3 analogs}

Preparation of all Grx3 analogs via NCL was carried out under folding conditions. ${ }^{51}$ The progress of the reaction was monitored by analytical HPLC, indicating that the reaction was complete within $4 \mathrm{~h}$, compared with $16 \mathrm{~h}$ under denaturating conditions $(6 \mathrm{M} \mathrm{GnHCl})$, affording the desired proteins in high yields (see Figure S1 in the Supporting Information). A typical reaction mixture included $10 \mathrm{mg}$ of the thioester-peptide analog ( 1.2 equiv) and $10 \mathrm{mg}$ Cyspeptide in $800 \mu \mathrm{L}$ phosphate buffer $(200 \mathrm{mM}, \mathrm{pH} 7.8, \sim 3 \mathrm{mM}$ peptide $)$ with $12 \mu \mathrm{L}(1.5 \% \mathrm{v} / \mathrm{v})$ thiophenol.

\section{Selective thermodynamic or kinetic active site oxidation and alkylation with iodoacetamide}

The active site of Grx3(C11U-C14U-A38C) was found to be oxidized in the presence of thiophenol while the ligation site Cys 38 remained reduced. ${ }^{54}$ In contrast, the mono-Sec analogs, Grx3(C11U-A38C) and Grx3(C14U-A38C), were partially reduced in the presence of thiophenol, and the active site of Grx3(A38C) was obtained predominantly in its reduced form. Following purification, the proteins were dissolved at $0.1 \mathrm{mg} / \mathrm{mL}$ in $200 \mathrm{mM}$ phosphate 
buffer ( $\mathrm{pH} 7.8$ ) and stirred open to air for $30 \mathrm{~min}$. This procedure resulted in exclusive oxidation of the active site selenenylsulfide bonds. Since the ligated Grx3(A38C), like the wt-Grx3, is an oxidizing enzyme,,, 55 this procedure failed, yielding a disulfide dimer at Cys 38 rather than the desired active site disulfide monomer. This problem was solved by a kinetically controlled oxidation of the active site using the Grx3 substrate, oxidized glutathione (GSSG). The addition of 1 equiv of GSSG resulted in rapid conversion to the active site disulfide product. All active site oxidized proteins were alkylated at Cys 38 without purification using excess iodoacetamide ( 1000-fold) and were purified by HPLC (see Figure S2 in the Supporting Information).

\section{Equilibration kinetics and redox potential determination}

The redox potential of oxidoreductases is typically determined using end-point analysis at equilibrium with a known redox pair, such as recombinant $E$. coli $\operatorname{Trx}\left(E^{0}=-270 \mathrm{mV}\right.$, Scheme 2). ${ }^{7}$ However, the high reactivity of reduced seleno-Grx3 analogs to trace oxidants made this approach impossible. Instead, the equilibration of equimolar Grx3 analogs (oxidized) and Trx (reduced) was easily followed as a function of time. First, the folded proteins were prepared by dissolving $1 \mathrm{mg}$ of each Grx 3 analog and $1 \mathrm{mg}$ of Trx in separate tubes using $100 \mu \mathrm{L}$ argondegassed potassium phosphate buffer. For each individual time point equimolar oxidized Grx3 analog and reduced Trx were mixed at room temperature and stopped by acid-quenching. The amount of reduced and oxidized Trx was determined using HPLC (Figure 2). The data was fit (Figure 3) to the second-order rate equation (see SI), which contains a term for a linear background oxidation These data are summarized in Table 1. The developed rate equation (see SI) enabled calculation of the second-order rate constants of the forward reaction, $k_{1}$ and of the reverse reaction, $k_{-1}$, (Table 1 and Scheme 2) and the equilibrium constant, $K_{\text {eq }}$ (Eq. 1). Using the Nernst equation, (Eq. 2), the redox potential differences between $\operatorname{Trx}(-270 \mathrm{mV})$ and each Grx3 analog were also determined and summarized in Table 1.

$$
\begin{gathered}
K_{e q}=\frac{k_{1}}{k_{-1}}=\frac{\left[G r x 3_{\text {red. }}\right]\left[\operatorname{Tr} x_{\text {ox. }}\right]}{\left[G r x 3_{\text {ox. }}\right]\left[\operatorname{Tr} x_{\text {red. }}\right]} \\
E=E_{0}-\frac{R T}{n F} \ln K_{e q}
\end{gathered}
$$

\section{Discussion}

\section{Design of seleno-Grx3 analogs}

Since most of the known selenoproteins are redox enzymes that operate via reversible formation of selenenylsulfide bonds, it is critical to understand the effect of an active site $\mathrm{S} /$ Se substitution on the enzyme's redox potential and kinetics. Specifically, the redox potential is a reflection of the relative rates of the selenol/disulfide exchange reaction. Depending on the position of Se in the enzyme and the direction of the reaction, it can act as a nucleophile, a central atom or as a leaving group (Scheme 3). Although small molecule studies have suggested that selenolates are both stronger nucleophiles and better leaving groups than the corresponding thiolates, it is not clear to what extent these intrinsic reactivities are maintained within the enzyme environment and how they affect enzyme kinetics. Grx3 was chosen as a model oxidoreductase for this study due to its intermediate redox potential within the Trx superfamily. 7. Both mono-Sec Grx3 analogs containing either CXXU or UXXC, and the diselenide analog with the UXXU motif were examined. In contrast to the Sec derivatives, the synthesis of sGrx3 was found to be more challenging because formation of the disulfide bond does not occur readily under air in this protein. In order to push this variant to the fully oxidized state, we added 1 equiv of GSSG. The redox potential of sGrx3 $(-194 \mathrm{mV})$ was found to be consistent within experimental error to that reported of wt-Grx3 (Table 1, entries 1 and 6). ${ }^{7}$ This result 
was confirmed by the wt-Grx1/sGrx3 equilibria ( $-197 \mathrm{mV}$; Tablet, entry 5), using the endpoint analysis. 7

\section{Redox kinetics}

The equilibration reactions between the oxidized Grx 3 analogs and reduced Trx were monitored by HPLC analysis of acid-quenched samples. Fitting the kinetic data (Figure 3) to the developed rate equation provided the second-order rate constants $k_{1}$, and $k_{-1}$, (Eq. 1) and $K_{\text {eq }}$, which enabled determination of the redox potentials. Interestingly, the $k_{1}$, values of all analogs were found to be largely independent of the Cys/Sec substitution at position 11 and/ or 14 (Table 1, Scheme 2). This observation suggests that within the protein environment, sulfur and selenium behave similarly when taking the role of either a central atom or a leaving group (Scheme 3). In contrast, the $k_{-1}$ values were found to be remarkably sensitive to the Cys/ Sec substitutions over a range of four orders of magnitude, with sGrx3 being the slowest and Grx3(C11U-C14U) being the fastest enzyme (Table 1). This observation is consistent with previous studies on CXXC mutants of Trx in which the second-order rate constants of reduction of oxidized Trx analogs by DTT were found to be the primary determinant of altered redox potential. ${ }^{27}$ The sGrx3/Trx thiol/disulfide exchange reaction involves a two-step mechanism (Scheme 3), and it seems likely that the Sec analogs utilize a similar mechanism. The significant increase in $k_{-1}$ observed in the seleno-Grx3 analogs is consistent with the greater nucleophilicity of the selenolate anion in comparison with that of the thiolate. ${ }^{56}$ Interestingly, the effects of Sec on $k_{-1}$ are largely additive, in terms of free energy, with either Grx3(C11U) or Grx3(C14U) exhibiting $k_{-1}$ with approximately $\sim 100$-fold greater than that of sGrx3. The double mutant, Grx3(C11U-C14U), exhibited $k_{-1}$ that was $\sim 9000$-fold higher than that of sGrx3.

\section{Single Sec incorporation into Grx3}

The two mono-Sec analogs, Grx3(C11U) and Grx3(C14U), contain a Sec residue in the $\mathrm{N}$ and C-terminal position of the ${ }^{11} \mathrm{CXX}^{14} \mathrm{C}$ motif. While Cys11 is solvent exposed and exhibits a suppressed $\mathrm{p} K_{\mathrm{a}}$, Cys 14 is largely hidden from solvent and has a higher $\mathrm{p} K_{\mathrm{a}} .57,58$ In reduced Grx3 the upper limit for the $\mathrm{p} K_{\mathrm{a}}$ of Cys11 ( $\left.K_{\mathrm{a}}<5.5\right)$ and the lower limit for $\mathrm{p} K_{\mathrm{a}}$ Cys 14 $\left(\mathrm{p} K_{\mathrm{a}},>10.5\right)$ were determined experimentally by direct NMR titration. ${ }^{58}$ Since Grx3 unfolds at $\mathrm{pH}$ values below 5.5 and above 10.5, precise values were not measurable. However, the actual $\mathrm{p} K_{\mathrm{a}}$ 's are expected to be at least 1 unit further away from these limits, 58 and clearly demonstrate that Cys 11 is largely in the anionic form and Cys14 is neutral at physiological pH. 58 Inspection of the dithiol mechanism (Scheme 3 ) shows that both residues act as a nucleophile in different steps of the catalytic mechanism. Since the $\mathrm{p} K_{\mathrm{a}}$, of Sec is three units lower than that of Cys, it is expected that Sec 11 would be largely deprotonated while Sec14 would still be in the neutral selenol form at neutral $\mathrm{pH} .{ }^{59}$ Despite the different protonation states of these residues, the position of the Sec residue does not have a large effect on the redox potential of the selenenylsulfide bond in the context of the Grx3 active site. The redox potentials of Grx3 (C11U) (-260 mV; Table 1, entry 2) and Grx3(C14U) (-275 mV; Table 1, entry 3) are within $15 \mathrm{mV}$ of each other and are similar to the most reducing member in the thiol/disulfide oxidoreductase family in E. coli, Trx ( $-270 \mathrm{mV}$; Table 1, entry 8). Although both mono-Sec analogs have greatly accelerated back reactions (Scheme 2), Grx3(C14U) shows a 5-fold decrease in the forward reaction as well. This suggests that Sec14 is a worse leaving group $\left(k_{1^{\prime}}\right)$ in the context of Grx3, possibly due to destabilization of the selenolate group in the hydrophobic environment surrounding residue 14 . This effect is not seen in the forward reaction

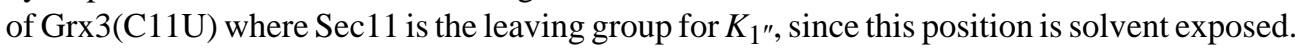
Although it might seem surprising that Sec exerts its primary effect on redox potential by acting as a potent nucleophile rather than as a leaving group, this relationship is required in order to change the redox equilibrium. In order to decrease the redox potential by $\sim 70 \mathrm{mV}$, the nucleophilicity of Sec must be increased by $\sim 2.5$ orders of magnitude more than the 
enhancement, if any, of Sec as a leaving group (Scheme 3). If both rates were equally enhanced, no change in redox potential would be observed.

\section{Natural selenoenzymes}

The redox potentials of the mono-Sec Grx3 analogs provide insight into other selenenylsulfide bonds in enzymes. For example, a family of eukaryotic selenoproteins has been identified with an active site sequence that is analogous to Grx3(C14U). The NMR structure of two of these proteins, Sep 15 and Se1M, revealed that they represent a new Trx-like protein family containing active-site motifs of CGU and CGGU, respectively. ${ }^{23}$ Although the oxidized form of Sep 15 contains a selenenylsulfide bond, it was not possible to express wt-Sep15 in sufficient quantities for redox analysis, so the redox potential of its disulfide analog, CGC, was determined instead $(-225 \mathrm{mV}){ }^{23}$ It was predicted that the redox potential of wt-Sep15 (CGU) would be similar to that of the CGC analog. In contrast, our results suggest that substitution of Cys by Sec significantly lowers the redox potential, by an average of $73 \mathrm{mV}$ for the two monoSec analogs of Grx3. Conferring these properties to wt-Sep15 would suggest the redox potential is in the range of $-300 \mathrm{mV}$. Recently, it has been shown that the selenoenzyme methionine$R$-sulfoxide reductase (MsrB1) forms a selenenylsulfide bond in its catalytic cycle. Although this bond was reported to be reduced directly by Trx ${ }^{8}$ the redox potential of MsrB1 is still unknown. Our results demonstrate that selenenylsulfide bonds in enzymes are in rapid equilibrium with Trx and can be tuned to be even more oxidizing than Trx. Thioredoxin reductase (TrxR) contains a C-terminal selenenylsulfide bond, ${ }^{6,11}$ which is reduced directly by a pair of Cys residues located near the N-terminus of this enzyme. ${ }^{6,11}$ This suggests that the redox potential of this disulfide is not significantly lower than that of the selenenylsulfide. ${ }^{60}$ Furthermore, a recently discovered ResA from $B$. subtilis that contains the CXXC motif, achieves a low redox potential $(-340 \mathrm{mV})^{61}$ without requiring Sec substitution. ResA was suggested to be the protein responsible for reducing oxidized cytochrome $c 550 .{ }^{62}$ Finally, the UXXC motif has been found in the N-terminal domain of two structurally homologous proteins: the human selenoprotein $\mathrm{P}(\mathrm{Se} 1 \mathrm{P}){ }^{63}$ and the zebrafish zSe1Pa. ${ }^{10}$ While in Se1P this motif exhibited glutathione peroxidase (GPx) activity, ${ }^{64} \mathrm{zSe} 1 \mathrm{~Pa}$ is thought to have selenol/ disulfide oxidoreductase activity. ${ }^{10}$ The Grx3(C11U) analog suggests that zSe1Pa should have a redox potential in the vicinity of Trx, and future studies will be directed toward the ability of synthetic seleno-Grx3 analogs to act as peroxidases.

\section{The diselenide enzyme, Grx3(C11U-C14U), has a low redox potential and fast kinetics}

Although several natural selenoproteins that contain multiple Sec residues have been reported, 65 the presence of diselenide bonds in natural proteins has not yet been established. Therefore, the synthetic diselenide analog, Grx3(C11U-C14U), provides an interesting opportunity to study this bond within a protein environment. Grx3(C11U-C14U) was found to have a redox potential of $-309 \mathrm{mV}$ (Table 1, entry 4), which is $115 \mathrm{mV}$ lower than that of sGrx3, corresponding to a change of $5.5 \mathrm{kcal} / \mathrm{mol}$ in redox potential. This result is consistent with the redox potential of $\operatorname{Trx}(\mathrm{C} 32 \mathrm{U}-\mathrm{C} 35 \mathrm{U})$, which was previously estimated to be somewhere between Trx $(-270 \mathrm{mV})$ and DTT $(-323 \mathrm{mV}),{ }^{37}$ and with the monoselenol selenocystamine $(-348 \mathrm{mV})^{54}$ but is significantly higher than previous diselenide-peptide studies $(-380 \mathrm{mV})$. 40 Although the redox potential of the diselenide analog, Grx3(C11U-C14U), is lower than that of Trx, at equilibrium $\sim 19 \%$ of this analog is in the reduced form (Figure 2D), which suggests that Trx can act as an effective reductant for diselenide bonds in proteins. The $\sim 9000-$ fold increase in $k_{-1}$ for the diselenide, combined with a physiologically compatible redox potential, suggests that diselenide selenoenzymes may have a role in biological catalysis. 


\section{Selenocysteine as a tool for protein engineering}

The relative stability of selenenylsulfide bonds compared to diselenide bonds has generated significant interest in protein engineering. The low redox potential of diselenide bonds could stabilize proteins towards reduction as shown with the disulfide rich peptides apamin and dconotoxin ImI. ${ }^{66,42}$ Although the redox potential of Grx3(C11U-C14U) $(-309 \mathrm{mV})$ is significantly below that of the two mixed selenenylsulfide analogs $(-260 \mathrm{mV}$ and $-275 \mathrm{mV})$, the sum of two selenenylsulfide bonds compared to a disulfide $(-194 \mathrm{mV})$ and a diselenide $(-309 \mathrm{mV})$ would be slightly in favor of the two mixed selenenylsulfide bonds by $16 \mathrm{mV}$ per bond, a trend also seen in peptide studies, ${ }^{40}$ and consistent with small molecule selenenylsulfide bonds that do not disproportionate into disulfides and diselenides. 67,68 Relative stability of these bonds is clearly dependent on the context of the protein structure and the $\mathrm{pH}$ of the aqueous media. The incorporation of Sec residues into proteins could increase the kinetics of disulfide exchange as found in small molecule systems. ${ }^{54}$ In addition, diselenides can be formed selectively at low $\mathrm{pH}^{42}$ and may be kinetically trapped from exchange under monothiol reducing environments. ${ }^{54}$ However, the near additive redox potentials of the seleno-Grx3 analogs suggest that caution should be taken when incorporating Sec to direct the formation of native and non-native disulfide bonds in proteins.

\section{Conclusions}

The synthesis of a complete set of Sec variants in the active site disulfide of glutaredoxin 3 provides insights into the catalytic machinery of selenoenzyme. In the context of an active site, single Sec substitutions significantly lower the redox potential of the active site to a level similar to that of thioredoxin. Although diselenide bonds have not yet been observed in selenoenzymes, we find that active site diselenides can have low but biologically compatible redox potentials, suggesting a possible role for diselenides in selenoenzyme catalysis. Significantly, the effects of Sec on the reaction kinetics suggest that the difference in nucleophilicity between selenolate and thiolate groups could provide the bulk of the rate enhancement observed in many selenoenzymes. As a result, protein engineering with Sec may enhance the rate of numerous enzymes that utilize nucleophilic cysteine residues.

\section{Experimental Section}

\section{Materials and Methods}

Buffers for kinetic measurements were prepared using de-ionized water (MilliQ). $\mathrm{KH}_{2} \mathrm{PO}_{4}$ and $\mathrm{K}_{2} \mathrm{HPO}_{4}$ were purchased from Fisher Biotech. Recombinant E. coli Trx 1 and Grx 1 were purchased from Promega Corporation (Madison, WI) and American Diagnostica Inc. (Greenwich, CT), respectively. Deuterated solvents (DMSO- $d_{6}$ and $\mathrm{CDCl}_{3}$ ) were purchased from Aldrich Chem. Co.

\section{Protein sequence and design}

The amino acid sequence of the wild-type Grx3 is:

\section{${ }^{1}$ ANVEIYTKET ${ }^{11}$ CPY $^{11}$ CHRAKAL LSSKGVSFQE LPIDGN ${ }^{37} \mathrm{~A}^{38} \mathrm{AKR}$ EE $^{43}$ MIKRSGRT ${ }^{51}$ TVPQIFIDAQ HIGG ${ }^{65}$ CDDLYA LDARGGLDPL L $^{82} \mathrm{~K}$}

The sGrx3 protein used in this work contains substitutions: Met43Nle (norleucine) and Cys65Tyr to prevent undesired oxidative side reactions. ${ }^{33}$ In addition, Ala38Cys was used for $\mathrm{NCL}$ and was subsequently alkylated with iodoacetamide to give Ala38Cys $\left(\mathrm{S}-\mathrm{CH}_{2} \mathrm{CONH}_{2}\right)$. The seleno-Grx3 analogs contained the above-mentioned substitutions with additional Sec at position 11 and/or 14. 


\section{Synthesis of N-Boc-L-Se(4-methylbenzyl)Sec-OH}

N-Boc-L-Ser(OTos)-OMe, 3 was synthesized according to van der Donk 48 using N-Boc-LSer-OMe, 2.69

bis-(4-Methylbenzyl)-diselenide, 4-Following the procedure of Tian et al. ${ }^{52}$ elemental selenium (7.1 g, $90 \mathrm{mmol})$, water $(20 \mathrm{~mL}), \mathrm{DMF}(160 \mathrm{~mL})$ and 4-methylbenzaldehyde $(3.6 \mathrm{~g}$, $30 \mathrm{mmol}$ ) were added to a $250 \mathrm{~mL}$ three-nicked flask equipped with a stirrer, condenser and gas bubbler. The mixture was stirred at $100{ }^{\circ} \mathrm{C}$ under $\mathrm{CO}$ for $7 \mathrm{~h}$, then was stirred overnight under air to complete the oxidative dimerization. Water $(100 \mathrm{~mL})$ was added and the mixture was filtered through a silica-gel pad, washed with $\mathrm{Et}_{2} \mathrm{O}$ and then extracted with $\mathrm{Et}_{2} \mathrm{O}$. The organic phase was dried over $\mathrm{MgSO}_{4}$, filtered and the solvent was removed under reduced pressure to yield bis-(4-methylbenzyl)-diselenide, $4(10 \mathrm{~g}, 88 \%)$ in the form of a yellow-orange solid. ${ }^{1} \mathrm{H}-\mathrm{NMR}\left(300 \mathrm{MHz}, \mathrm{CDCl}_{3}\right) \delta 7.07$ (s, 8H), $3.8(\mathrm{~s}, 4 \mathrm{H}), 2.3(\mathrm{~s}, 6 \mathrm{H})$.

N-Boc-L-Se(4-methylbenzyl)Sec-OMe, 6-Following the procedure of van der Donk, 48 compound 4 (24 g, $64.72 \mathrm{mmol}$ ) and N-Boc-L-Ser(OTos)-OMe, 3 (15.05 g, $40.3 \mathrm{mmol}$ ) were reacted and purified by column chromatography to give $\mathbf{6}(10 \mathrm{~g}, 64 \%) .{ }^{1} \mathrm{H}-\mathrm{NMR}$ (300 $\left.\mathrm{MHz}, \mathrm{CDCl}_{3}\right) \delta 7.14(\mathrm{~d}, \mathrm{~J}=8.1 \mathrm{~Hz}, 2 \mathrm{H}), 7.08(\mathrm{~d}, \mathrm{~J}=8.1 \mathrm{~Hz}, 2 \mathrm{H}), 5.27(\mathrm{~d}, \mathrm{~J}=6.9 \mathrm{~Hz}, 1 \mathrm{H}), 4.6$ $(\mathrm{m}, 1 \mathrm{H}), 3.74(\mathrm{~s}, 2 \mathrm{H}), 3.72(\mathrm{~s}, 3 \mathrm{H}) 2.87(\mathrm{t}, \mathrm{J}=4.5 \mathrm{~Hz}, 2 \mathrm{H}), 2.3(\mathrm{~s}, 3 \mathrm{H}), 1.43(\mathrm{~s}, 9 \mathrm{H})$. MS: $[\mathrm{MNa}]^{+}=410$.

N-Boc-L-Se(4-methylbenzyl)Sec-OH, 7-Compound 6 was hydrolyzed by mixing it under argon with trimethyltin hydroxide ${ }^{53}$ (7 equiv) in degassed 1,2 -dichloroethane at $80{ }^{\circ} \mathrm{C}$ for $3 \mathrm{~h}$. Purification by column chromatography over silica-gel afforded $7(95 \%)$ in the form of white powder. ${ }^{1} \mathrm{H}-\mathrm{NMR}\left(500 \mathrm{MHz}, \mathrm{CDCl}_{3}\right) \delta 7.14(\mathrm{~d}, J=8 \mathrm{~Hz}, 2 \mathrm{H}), 7.06(\mathrm{~d}, J=8 \mathrm{~Hz}, 2 \mathrm{H})$, $5.28(\mathrm{bd}, J=4.5 \mathrm{~Hz}, 1 \mathrm{H}), 4.58(\mathrm{bd}, J=3 \mathrm{~Hz}, 1 \mathrm{H}), 3.76(\mathrm{~s}, 2 \mathrm{H}), 2.91$ (bs, $2 \mathrm{H}), 2.29$ (s, 3H), 1.43 (s, 9H). MS: $[\mathrm{MH}]^{+}=374,[\mathrm{MNa}]^{+}=396$.

Peptide Synthesis-All peptides were prepared by machine-assisted solid-phase peptide synthesis (SPPS), typically on a $0.2 \mathrm{mmol}$ scale using the in situ neutralization/HCTU activation procedure for Boc-SPPS. ${ }^{70}$ The peptide coupling was carried out with 11-fold excess (except for norleucine and Sec, which were used in 3-fold excess) of activated amino acid for $20 \mathrm{~min}$. The trityl protecting group of the TAMPAL-Pam resin was first removed by a mixture of TFA:triisopropylsilane: $\mathrm{H}_{2} \mathrm{O}, 95: 2.5: 2.5$, and then transferred to the machine for the synthesis of the thioester peptides as described above. The Cys-peptide Grx3(Cys38-Lys82) was synthesized using the $\mathrm{Boc}-\mathrm{Lys}(2 \mathrm{ClZ})-\mathrm{OCH}_{2}-\mathrm{Pam}$ resin as described above.

Sec-coupling-The coupling of the Boc-Sec(4-MeBzl)-OH was carried out manually using a DIC/HOBt activation method, using Sec $(0.5 \mathrm{mmol}$ in $2 \mathrm{~mL}$ of $50 \% \mathrm{DCM} / \mathrm{DMF})$ and activated with DIC $(0.5 \mathrm{mmol})$ in the presence of $\mathrm{HOBt}(0.52 \mathrm{mmol})$ at $0{ }^{\circ} \mathrm{C}$ for $5 \mathrm{~min}$. The Boc group on resin-bound peptide was deprotected, neutralized with DIEA $(2 \times 1 \mathrm{~min})$ and washed with DMF. The activated Sec was then added to the resin and the mixture was kept at room temperature for $1 \mathrm{~h}$. Upon completion of the polypeptides assembly it was deprotected and cleaved from the resin by treatment of the dry peptide-resin $(\sim 300-400 \mathrm{mg})$ with $10-15$ $\mathrm{ml} \mathrm{HF}$ and $\sim 10 \%$ anisole for $1 \mathrm{~h}$ at $0{ }^{\circ} \mathrm{C}$. The crude peptide products were precipitated and washed with cold anhydrous ether, dissolved in aqueous acetonitrile and immediately purified by preparative, reversed-phase HPLC.

Conformationally assisted ligation-Preparation of all Grx 3 analogs via native chemical ligation was carried out under folding conditions. ${ }^{51}$ The progress of the reaction was followed by analytical HPLC, indicating that the reaction was complete within $4 \mathrm{~h}$, affording the desired protein in high yields (Figure S1, 40-50\% recovered). ${ }^{71}$ A typical reaction mixture included 
$10 \mathrm{mg}$ of the thioester-peptide analog ( 1.2 equiv.), $10 \mathrm{mg}$ Cys-peptide in $800 \mu \mathrm{L}$ phosphate buffer ( $200 \mathrm{mM}, \mathrm{pH} 7.8, \sim 3 \mathrm{mM}$ peptide), and $12 \mu \mathrm{L}(1.5 \% \mathrm{v} / \mathrm{v})$ thiophenol, the ligation was performed at room temperature with periodic vortexing.

Active site oxidation and Cys38 alkylation with iodoacetamide-In the case of Grx 3 (C11U-C14U-A38C) the resultant diselenide (oxidized form) was found to be stable in the presence of thiophenol in the ligation mixture. At the end of the ligation the excess thiophenol was removed by extraction with $\mathrm{Et}_{2} \mathrm{O}(3 \times 2 \mathrm{~mL})$. Alkylation of Cys 38 with iodoacetamide was achieved by addition of excess iodoacetamide ( $\sim 1000$-fold) to the erode ligation mixture to produce Grx3(C11U-C14U-A38Cys $\left(\mathrm{S}_{-} \mathrm{CH}_{2} \mathrm{CONH}_{2}\right)$ ) or abbreviated Grx3(C11U-C14U), which was purified by semi-preparetive HPLC (41\% recovered yield for the two steps).

In the case of the other three analogs, Grx3(A38C), Grx3(C11U-A38C) and Grx3(C14UA38C), the presence of thiophenol in the ligation mixture resulted in mixtures of the reduced and oxidized forms. Therefore, it was necessary to purify the ligated proteins and oxidize them to produce either the disulfide or the corresponding selenenylsulfide bond. This oxidation was carried out by dissolving each protein ( $~ 8 \mathrm{mg})$ in $100 \mathrm{~mL}$ phosphate buffer $(200 \mathrm{mM}$, pH 7.8) and stirring the mixture in an open flask for $\sim 30 \mathrm{~min}$ (Figure S2). In the case of Grx3(A38C) it was necessary to add 1 equiv. of oxidized glutathione (GSSG) in order to complete the oxidation process (any dimer formation was separated and recovered). Finally, excess iodoacetamide ( $\sim 1000$-fold) was added and the resultant protein was purified by semipreparative HPLC.

Equilibration kinetics and redox potential determination-Determining the redox potential was similar to the method of Holmgren, ${ }^{7}$ by equilibration of equimolar Grx 3 analogs (oxidized) and Trx (reduced), which was followed as a function of time. First, the folded proteins were prepared by dissolving $1 \mathrm{mg}$ of each Grx3 analog and $1 \mathrm{mg}$ of Trx in separate tubes using $100 \mu \mathrm{L}$ argon-degassed potassium phosphate buffer $(100 \mathrm{mM}, \mathrm{pH} 7.07,1 \mathrm{mM}$ EDTA) and allowing them to stand for 30-60 minutes at room temperature. The equilibrium reactions (5-12 $\mu \mathrm{L}$ typically contained $100-270 \mu \mathrm{M}$ of each of the two redox-active proteins in a degassed and argon-purged solution of potassium phosphate $(100 \mathrm{mM}, \mathrm{pH} 7.07,1 \mathrm{mM}$ EDTA). The reduced form of Trx was prepared immediately before use by incubation of the protein $(\sim 500 \mu \mathrm{M}$ in $50 \mathrm{mM}$ dithiothreitol at room temperature for $1 \mathrm{~h}$, followed by extensive centrifugation-dialysis (Amicon Ultra, cutoff $5000 \mathrm{Da}$, Millipore Corporation, Bedford, MA) by degassed potassium phosphate buffer $(8 \times 2 \mathrm{~mL})$. The concentration of each protein was determined by UV (HP 8452A Diode-Array), using the following $\varepsilon 280 \mathrm{~nm}$ values: Trx $\left(\varepsilon_{280 \mathrm{~nm}}=13700 \mathrm{~cm}^{-1} \mathrm{M}^{-1}\right) ; \operatorname{sGrx} 3\left(\varepsilon_{280 \mathrm{~nm}}=6050 \mathrm{~cm}^{-1} \mathrm{M}^{-1}\right)$; Grx3(C11U) orGrx $(\mathrm{C} 14 \mathrm{U})$ $\left(\varepsilon_{280 \mathrm{~nm}}=5990 \mathrm{~cm}^{-1} \mathrm{M}^{-1}\right)$; Grx3 $(\mathrm{C} 11 \mathrm{U}-\mathrm{C} 14 \mathrm{U})\left(\varepsilon_{280 \mathrm{~nm}}=5920 \mathrm{~cm}^{-1} \mathrm{M}^{-1}\right)$. The $\varepsilon_{280 \mathrm{~nm}}$ values were calculated using Sherpa $_{\mathrm{Lite}}{ }^{4.0}$ for Mac.

Redox equilibration of the Grx3 analogs was carried out separately for each time point by mixing the reduced Trx and oxidized Grx 3 analog in an Eppendrof tube at room temperature using degassed potassium phosphate buffer. The reaction was stopped after the desired time interval (from $3 \mathrm{sec}$ to $10 \mathrm{~min}$ in analogs that contain Sec and to $2 \mathrm{~h}$ for the sGrx3) by adding $\mathrm{HCl}(80 \mu \mathrm{L}, 1 \mathrm{M})$ followed by immediate HPLC analysis to avoid oxidation of the seleno-Grx3 analogs. The oxidized and reduced forms of $\operatorname{Trx}^{72}$ were well separated by reverse phase HPLC (Varian) on a $\mathrm{C}_{18}$ column (Phenomenex Jupiter $5 \mu \mathrm{m}, 300 \AA$, $150 \times 4.6 \mathrm{~mm}$ ) using a gradient from $35-70 \%(\mathrm{v} / \mathrm{v}$ ) buffer $\mathrm{B}$ in $25 \mathrm{~min}$ at a flow rate of $1 \mathrm{ml} / \mathrm{min}$ at room temperature, monitoring at $220 \mathrm{~nm}$. The amounts of oxidized and reduced forms of Trx in the quenched equilibrium mixture were obtained from the chromatograms by peak area integration, each time point is the average of two separate experiments. The data was fit to the second-order rate equation (see SI), which contains a term for a linear background oxidation (only observed for Sec containing analogs). These data are summarized in Table 1. The second-order rate 
constants $\left(k_{1}\right.$ and $\left.k_{-1}\right)$, as well as the equilibrium constant, $K_{\mathrm{eq}}$ (Eq. 1$)$ were calculated by fitting the data to the kinetic model. The difference in redox potential between Trx and each of the Grx3 analog, $\Delta \mathrm{E}$, was calculated according to the Nernst equation (Eq. 2), where $n$ is the number of electrons transferred (here $n=2), F$ is Faraday's constant $\left(23.04 \mathrm{kcal} \cdot \mathrm{mol}^{-1} \cdot \mathrm{V}^{-1}\right), R$ is the gas constant $\left(1.987 \mathrm{cal} \cdot \mathrm{K}^{-1} \cdot \mathrm{mol}^{-1}\right)$, and T is the absolute temperature $(298 \mathrm{~K})$.

\section{Supplementary Material}

Refer to Web version on PubMed Central for supplementary material.

\section{Acknowledgements}

We thank the Israel-US Binational Science Foundation, the German-Israeli Project Cooperation (DIP) (EK), NIH GM059380 (FED), the Israeli Higher Education Planning and Budgeting Committee and Israel Ministry of Science (NM) and the Skaggs Institute for Chemical Biology for financial support. We also want to thank Dr. John Blankenship for unpublished work on the synthesis and mutagenesis of glutaredoxin, Dr. Michael Churchill for help with the peptide syntheses,

\section{References}

1. Flohe L, Gunzler EA, Schock HH. FEBS Lett 1973;32:132. [PubMed: 4736708]

2. Rotruck JT, Pope AL, Ganther HE, Swanson AB, Hafeman DG, Hoekstra WG. Science 1973;179:588. [PubMed: 4686466]

3. Stadtman TC. Ann Rev Biochem 1996;65:83-100. [PubMed: 8811175]

4. Stadtman TC. Ann NY Acad Sci 2000;899:399-402. [PubMed: 10863556]

5. Arnold AP, Tan KS, Rabenstein DL. Inorg Chem 1986;25:2433.

6. Zhong L, Arner ESJ, Holmgren A. Proc Natl Acad Sci USA 2000;97:5854-5859. [PubMed: 10801974]

7. Åslund F, Berndt KD, Holmgren A. J Biol Chem 1997;272:30780-30786. [PubMed: 9388218]

8. Kim H-Y, Gladyshev VN. PloS Biology 2005;3:2080-2089.

9. a) Ganther HE. Carcinogenesis 1999;20:1657-1666. [PubMed: 10469608] b) Becker K. Eur J Biochem 2000;267:6118-6125. [PubMed: 11012663]

10. Kryukov GV, Gladyshev VN. Genes to Cells 2000;5:1049-1060. [PubMed: 11168591]

11. Lee SR, Bar-Noy S, Kwon J, Levine RL, Stadtman TC, Rhee SG. Proc Natl Acad Sci USA 2000;97:2521-2526. [PubMed: 10688911]

12. Gromer S, Johansson L, Bauer H, Arscott LD, Rauch S, Ballou DP, Williams CH Jr, Schirmer RH, Arner ESJ. Proc Nat Acad Sci USA 2003;100:2618-12623.

13. Gladyshev VN, Jeang KT, Wootton JC, Hatfield DL. J Biol Chem 1998;275:8910-8915. [PubMed: 9535873]

14. Korotkov KV, Novoselov SV, Hatfield DL, Gladyshev VN. Mol Cell Biol 2002;22:1402-1411. [PubMed: 11839807]

15. Gardikas-Vlamis A, Holmgren A. Methods Enzymol 2002;347:286-296. [PubMed: 11898418]

16. Eklund H, Cambillau C, Sjoberg BM, Holmgren A, Jornvall H, Hoog JO, Branden CI. EMBOJ 1984;3:1443-1449.

17. Martin JL. Structure 1995;3:245-250. [PubMed: 7788290]

18. Holmgren A. Structure 1995;3:239-243. [PubMed: 7788289]

19. Nelson JW, Creighton TE. Biochemistry 1994;33:5974-5983. [PubMed: 8180227]

20. Grauschopf U, Winther JR, Korber P, Zander T, Dallinger P, Bardwell JCA. Cell 1995;83:947-955. [PubMed: 8521518]

21. Dyson HJ, Jeng MF, Tennant LL, Slaby I, Lindell M, Cui DS, Kuprin S, Holmgren A. Biochemistry 1997;36:2622-2636. [PubMed: 9054569]

22. Jeng MF, Holmgren A, Dyson HJ. Biochemistry 1995;34:10101-10105. [PubMed: 7640264]

23. Ferguson AD, Labunskyy VM, Fomenko DE, Araç D, Chelliah Y, Amezcua CA, Rizo J, Gladyshev VN, Deisenhofer J. J Biol Chem 2006;281:3536-3543. [PubMed: 16319061] 
24. Krause G, Lundstrom J, Barea JL, Pueyo de la Cuesta C, Holmgren A. J Biol Chem 1991;266:94949500. [PubMed: 2033048]

25. Chivers PT, Laboissiere MCA, Raines RT. EMBO J 1996;16:2659-2667. [PubMed: 8654363]

26. Schultz LW, Chivers PT, Raines RT. Acta Cryst 1999;55:1533-1538.

27. Mössner E, Huber-Wunderlich M, Rietsch A, Beckwith J, Glockshuber R, Åslund F. J Biol Chem 1999;274:25254-25259. [PubMed: 10464247]

28. $21 \mathrm{mV}$ difference in redox potential is equivalent to $1 \mathrm{kcal} / \mathrm{mol}$ at room temperature.

29. Lin TY, Kim PS. Biochemistry 1989;28:5282-5287. [PubMed: 2669972]

30. Holmgren A. Proc Nat Acad Sci USA 1976;73:2275-2279. [PubMed: 7783]

31. Åslund F, Ehn B, Miranda-Vizuette A, Pueyo C, Holmgren A. Proc Nat Acad Sci USA 1994;97:98139817.

32. Bushweller JH, Billeter M, Holmgren A, Wüthrich K. J Bio Chem 1994;255:1585-1597.

33. Nordstrand K, Åslund F, Holmgren A, Otting G, Berndt KD. J Mol Biol 1999;286:541-552. [PubMed: 9973569]

34. Berry MJ, Banu L, Chen YY, Mandel SJ, Kieffer JD, Harney JW, Larsen PR. Nature 1991;353:27300276. [PubMed: 1832744]

35. Berry MJ, Banu L, Harney JW, Larsen PR. EMBO J 1993;12:3315-3322. [PubMed: 8344267]

36. Suppmann S, Persson BC, Böck A. EMBO J 1999;18:2284-2293. [PubMed: 10205181]

37. Müller S, Senn H, Gsell B, Vetter W, Baron C, Böck A. Biochemistry 1994;33:3404-3412. [PubMed: 8136378]

38. Wu ZP, Hilvert D. J Am Chem Soc 1989;111:4513-4514.

39. Rajarathnam K, Sykes BD, Dewald B, Baggiolini M, Clark-Lewis I. Biochemistry 1999;38:76537658. [PubMed: 10387004]

40. Besse D, Siedler F, Diercks T, Kessler H, Moroder L. Angew Chem Int Engl 1997;36:883-885.

41. Moroder LJ. Pept Sci 2005;11:187-214.

42. Armishaw CJ, Daly NL, Nevin ST, Adams DJ, Craik DJ, Alewood PP. J Biol Chem 2006;281:1413614143. [PubMed: 16500898]

43. Dawson PE, Muir TW, Clark-Lewis I, Kent SBH. Science 1994;266:776-779. [PubMed: 7973629]

44. Dawson PE, Kent SBH. Annu Rev Biochem 2000;69:923-960. [PubMed: 10966479]

45. Dawson PE, Churchill MJ, Ghadiri MR, Kent SBH. J Am Chem Soc 1997;119:4325-4329.

46. Hondal RJ, Nilsson BL, Raines RT. J Am Chem Soc 2001;123:5140-5141. [PubMed: 11457362]

47. Ralle M, Berry SM, Nilges MJ, Gieselman MD, Van der Donk WA, Lu Y, Blackburn NJ. J Am Chem Soc 2004;126:7244-7256. [PubMed: 15186162]

48. Gieselman MD, Xie L, Van der Donk W. Org Lett 2001;3:1331-1334. [PubMed: 11348227]

49. Quaderer R, Sewing A, Hilvert D. Helvetica Chimica Acta 2001;84:1197-1206.

50. Eckenroth B, Harris K, Turanov AA, Gladyshev VN, Raines RT, Hondal RJ. Biochemistry 2006;45:5158-5170. [PubMed: 16618105]

51. Beligere GS, Dawson PE. J Am Chem Soc 1999;121:6332-6333.

52. Tian R, Yu Z, Lu S. J Org Chem 2004;69:4520-4523. [PubMed: 15202911]

53. Nicolaou KC, Estrada AA, Zak M, Lee SH, Safina BS. Angew Chem Int Ed 2005;44:2-6.

54. Singh R, Whitesides GM. J Org Chem 1991;56:6931-6933.

55. Sandberg VA, Kern B, Fuchs JA, Woodward C. Biochemistry 1991;30:5475-5484. [PubMed: 2036416]

56. Johansson L, Gafvelin G, Arnér ESJ. Biochem Biophys Acta 2005;1726:1-13. [PubMed: 15967579]

57. Chivers PT, Prehoda KE, Raines RT. Biochemistry 1997;36:4061-4066. [PubMed: 9099998]

58. Nordstrand K, Åslund F, Meunier S, Holmgren A, Otting G, Berndt KD. FEBS Lett 1999:449, 196200. [PubMed: 10094505]

59. In principle, the $\mathrm{p} K_{\mathrm{a}}$, values of Sec in selenoproteins can be measured by ${ }^{77} \mathrm{Se}-\mathrm{NMR}$, although direct measurement of these values is not possible due to the instability of reduced Grx3 bellow pH 5 .

60. De Silva V, Woznichak MM, Burns KL, Grant KB, May SW. J Am Chem Soc 2004;126:2409-2413. [PubMed: 14982447] 
61. Erlendsson LS, Acheson RM, Hederstedt L, Le Brun NE. J Biol Chem 2003;278:17852-17858. [PubMed: 12637552]

62. Colbert CL, Wu Q, Erbel PJA, Gardner KH, Deisenhofer J. Proc Natl Acad Sci USA 2006;103:4410_ 4415. [PubMed: 16537372]

63. Saito Y, Sato N, Hayashi T, Tanaka A, Watanabe Y, Suzuki M, Saito E, Takahashi K. J Biol Chem 1999;274:2866-2871. [PubMed: 9915822]

64. Saito Y, Sato N, Hirashima M, Takebe G, Nagasawa S, Takahashi K. Biochem J 2004;381:841-846. [PubMed: 15117283]

65. Hatfield DL, Gladyshev VN. Mol Cell Biol 2002;22:3565-3576. [PubMed: 11997494]

66. Pegoraro S, Fiori S, Cramer J, Rudolph-Bohner S, Moroder L. Protein Sci 1999;8:1605-1613. [PubMed: 10452604]

67. du Mont WW, Mugesh G, Wismach C, Jones PG. Angew Chem Int Engl 2001;40:2486-2488.

68. Mugesh G, du Mont WW, Wismach C, Jones PG. ChemBioChem 2002;3:440-447. [PubMed: 12007178]

69. Garner P, Park JM. Org Syn, Coll 1998;9:300.

70. Schnolzer M, Alewood PP, Jones A, Alewood D, Kent SBH. Int J Pept Protein Res 1992;40:180193. [PubMed: 1478777]

71. Under denaturaion conditions $(6 \mathrm{M} \mathrm{GnHCl})$ the reaction took $16 \mathrm{hrs}$ to give the same yield.

72. The two forms of Trx were well separated under the HPLC conditions. The seleno-Grx 3 analogs could not be fully separated and the reduced form had partial irreversible adsorption to the reversed phase matrix. 

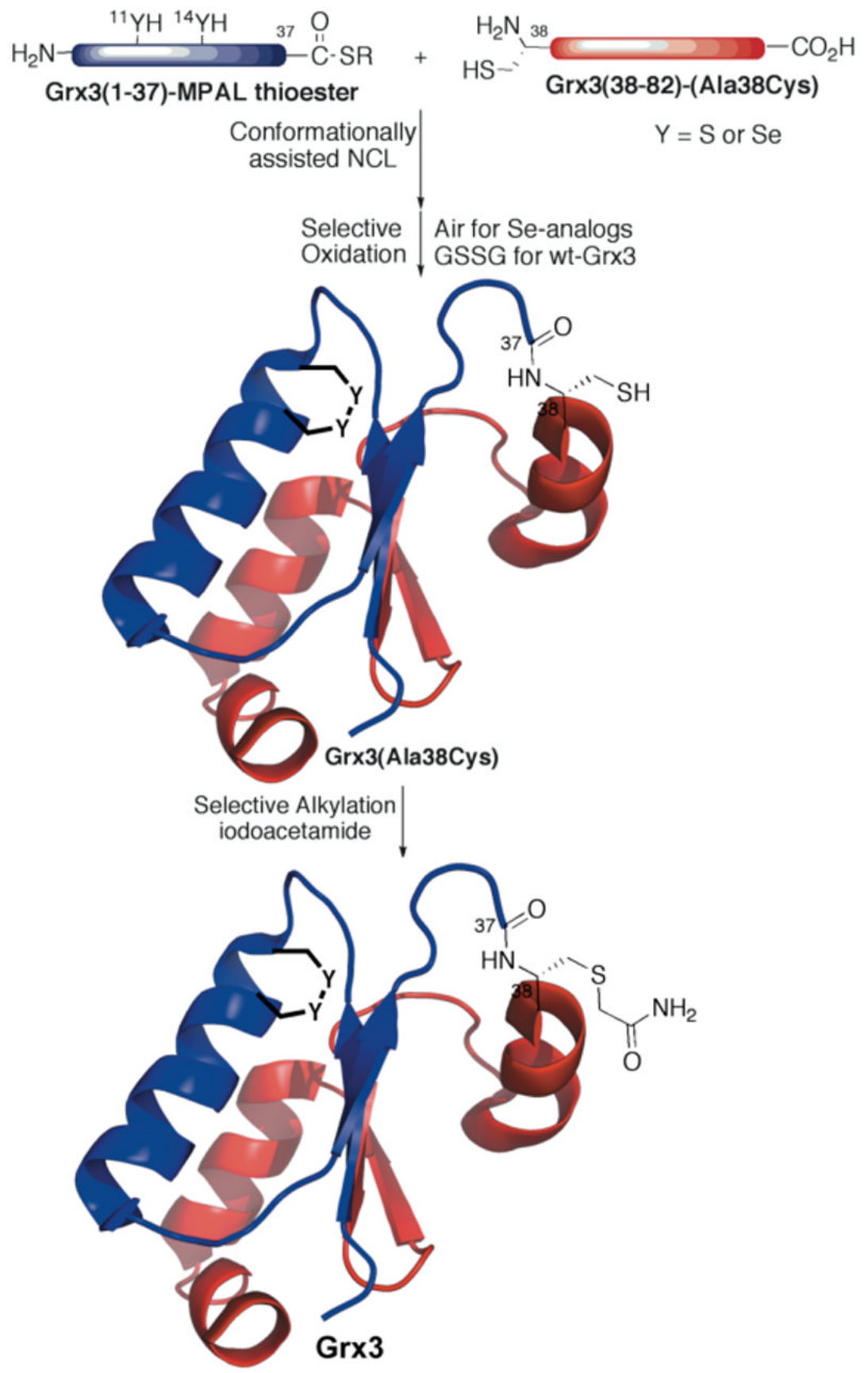

Figure 1.

Conformationally assisted NCL for chemical synthesis of Grx3 combined with selective oxidation and alkylation. For NCL the thioester-peptide Grx3(1-37)-MPAL (containing either Cys ( $\mathrm{Y}=\mathrm{S})$ or Sec $(\mathrm{Y}=\mathrm{Se})$, at positions 11 and/or 14), mixed with the Cys-peptide Grx3 (C38-82). After purification, the ligated product was oxidized to form the disulfide bond (or selenenylsulfide or diselenide bond) to protect them from the alkylation with iodoacetamide. $(\mathrm{MPAL}=\beta$-mercaptoproparionyl-Leu). 


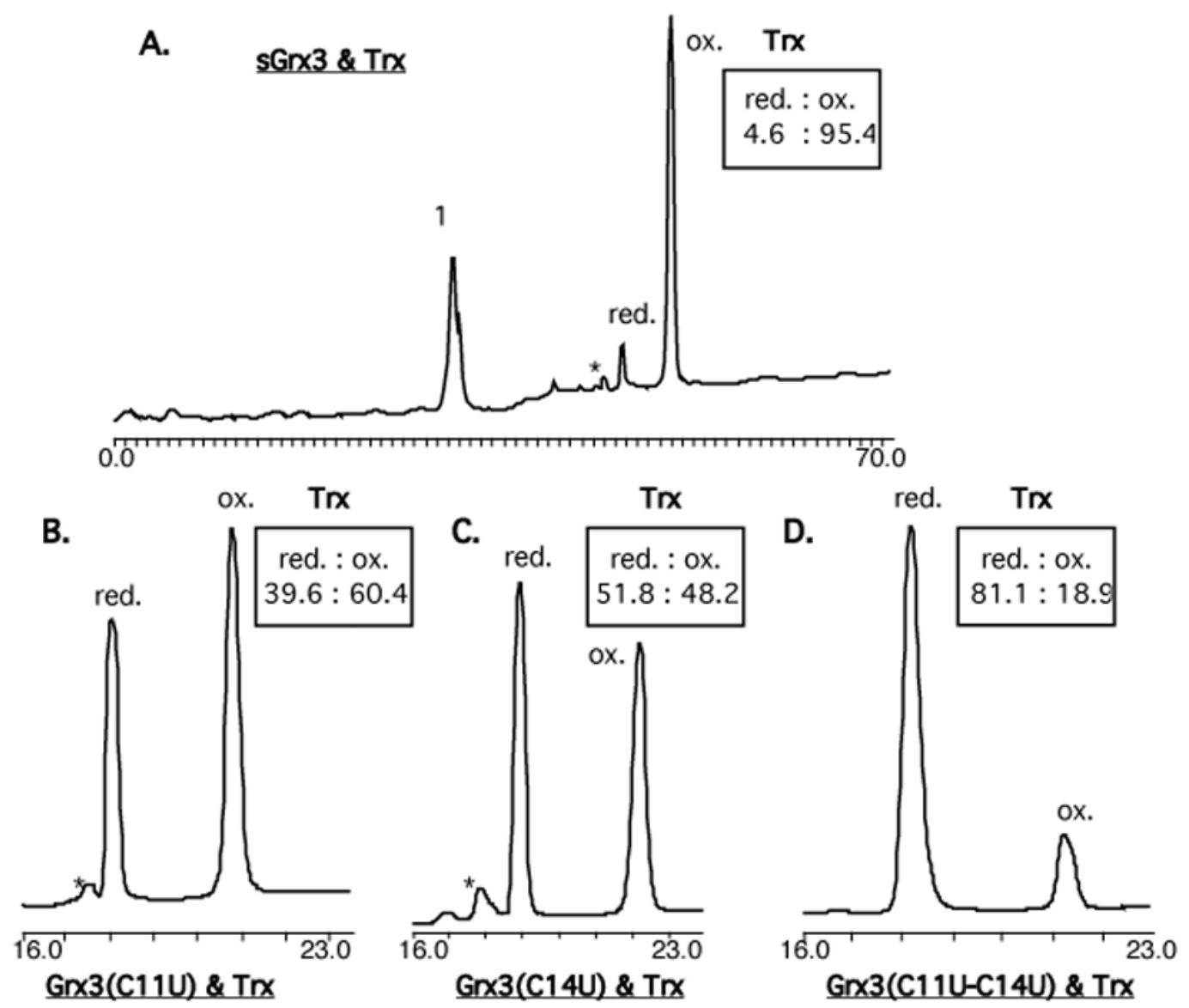

Figure 2.

HPLC chromatograms of species present after reaching equilibrium between equimolar amounts of reduced Trx and oxidized Grx3 analogs: A. sGrxS, B. Grx3(C11U), C. Grx3 $(\mathrm{C} 14 \mathrm{U}), \mathrm{D} . \mathrm{Grx3}(\mathrm{C} 11 \mathrm{U}-\mathrm{C} 14 \mathrm{U})$. Peak 1 contains the inseparable oxidized and reduced forms of sGrxS. An asterisk indicates the position of an oxygenated $(\mathrm{M}+16)$ methionine residue. 7 


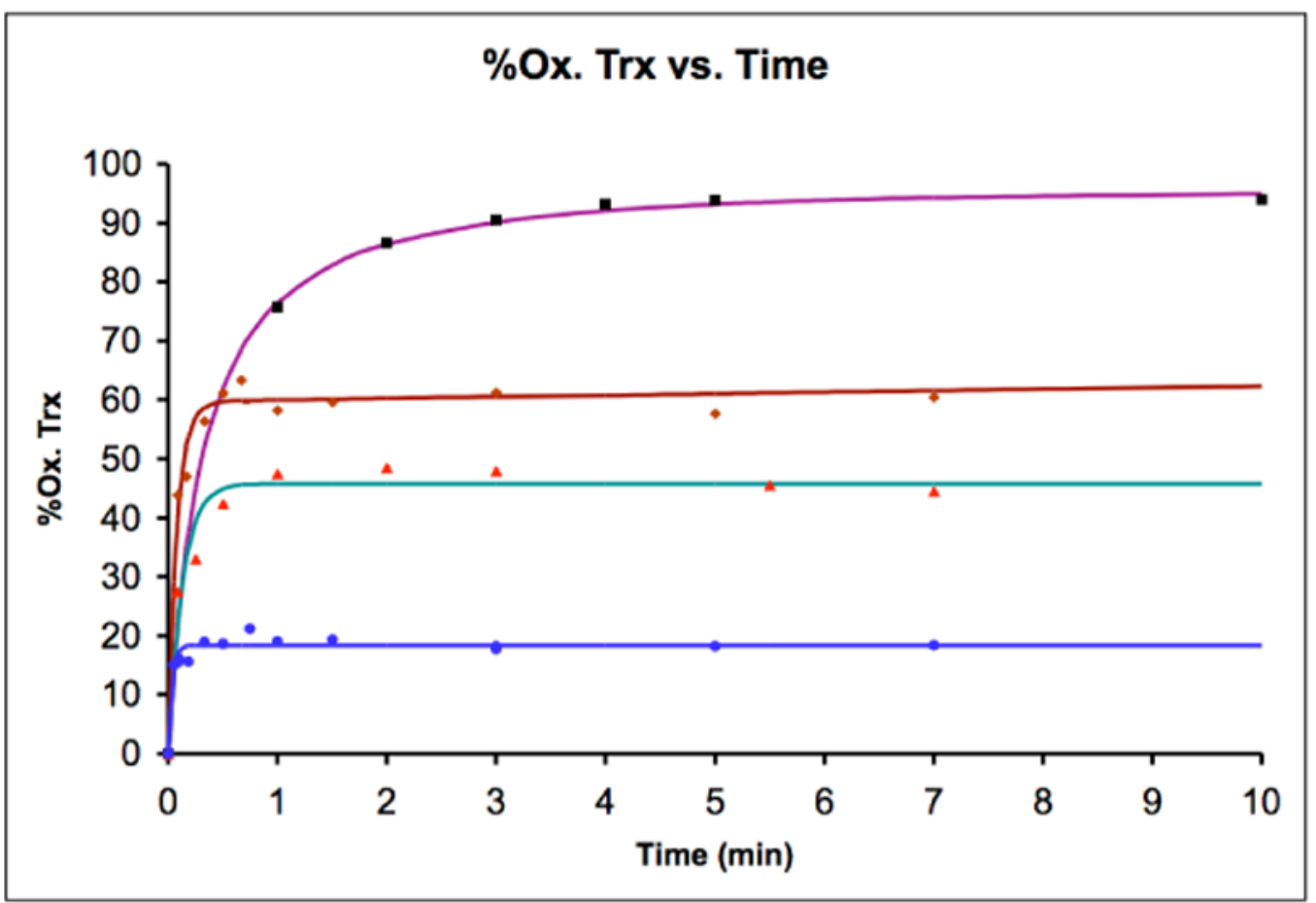

Figure 3.

The percentage of oxidized Trx formed as a function of time in the redox equilibrium of reduced Trx and oxidized Grx3 analogs: sGrxS (•); Grx3(C11U) (•); Grx3(C14U) ( $\bullet$ ); Grx3(C11U$\mathrm{C} 14 \mathrm{U})(\bullet)$. 


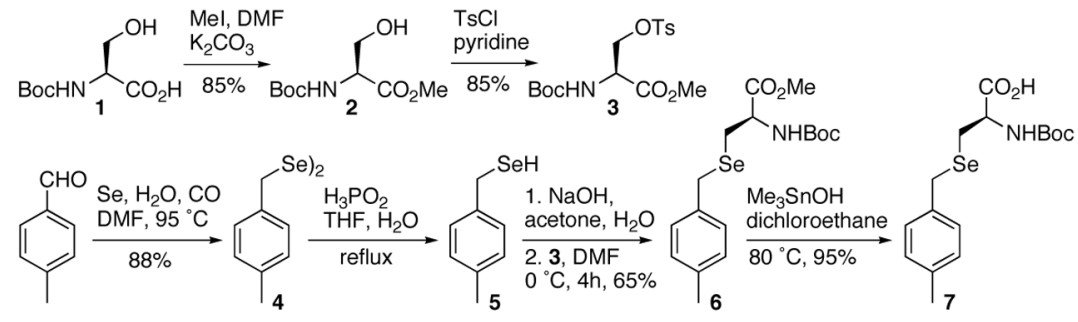

Scheme 1.

The synthetic route used to prepare Boc-(4-MeBzl)Sec-OH, 7. 


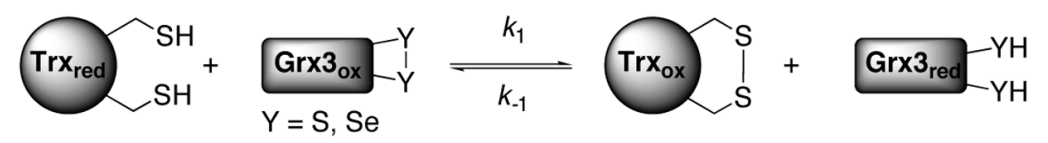

Scheme 2.

Direct protein-protein redox equilibria between Trx and Grx3 analogs. 


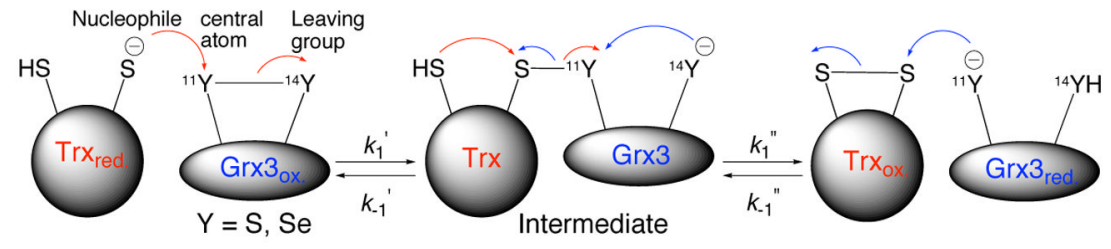

Scheme 3.

General mechanism of the redox exchange between Trx and Grx3 analogs. 


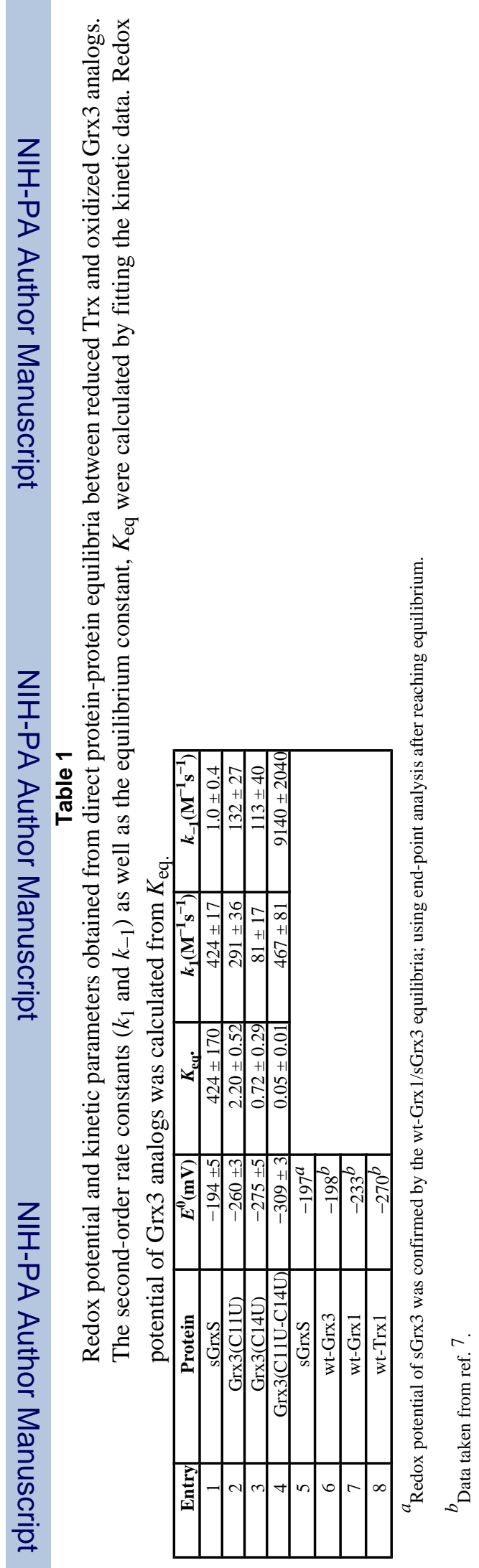

J Am Chem Soc. Author manuscript; available in PMC 2008 September 9. 